\title{
Research on Talents Training Mode of Mechanical and Electronic Engineering in the Universities of Applied Science and Technology
}

\author{
A Case Study on Huanghe Science \& Technology University*
}

\author{
Zengsheng Wang \\ Huanghe Science \& Technology University \\ Zhengzhou, China 450063
}

\author{
Wei Xiong \\ Huanghe Science \& Technology University \\ Zhengzhou, China 450063
}

\author{
Qinglian Meng \\ Huanghe Science \& Technology University \\ Zhengzhou, China 450063
}

\begin{abstract}
This paper summarizes the talents training mode of mechanical and electronic engineering in the University of Applied Science and Technology at home and abroad. Taking Huanghe Science and Technology University as an example, based on the investigation of the needs of professional talents, this paper puts forward a training program integrating skills training, foundation courses for entrepreneurship, and reinforcement of further studies, forming a classified training mode of employment orientation, entrepreneurial orientation and further study orientation. It has certain reference significance for the talents training in the field of mechanical and electronic engineering of University of Applied Science and Technology.
\end{abstract}

Keywords-university of applied science and technology; mechanical and electronic engineering major; talents training mode; classified training

\section{INTRODUCTION}

The University Applied Science and technology refers to a university characterized by applied science and technology rather than scientific research or others. In recent years, the number of universities of applied science and technology that set up mechanical and electronic engineering has increased. The mechanical and electronic engineering major develops the advanced engineering and technical personnel who can combine mechanical and electrical engineering, are able to master mechanical, electronic and computer application, and are able to engage in management of electromechanical equipment operation, and the design, development, operation and maintenance of new electromechanical products. The individual has their own development needs and plans, such as obtaining employment, starting a business, further studies and other different ways. How to build a talent training mode that adapts to the society and meets the personality

*Project source 2017 Teaching Reform Research and Practice Project in Higher Education in Henan (2017SJGLX127). development of students is a key issue for the universities of applied science and technology to be solved urgently.

\section{A SUMMARY OF TALENTS TRAINING MODE OF} DOMESTIC AND FOREIGN MECHANICAL AND ELECTRONIC ENGINEERING

The talents training mode of mechanical and electronic engineering in the university of applied science and technology at home and abroad mainly focuses on innovation and entrepreneurship, engineering quality, ability training, combination of production, teaching and research, etc. The specific training modes include:

\section{A. Integrate the Talents Training Mode of Innovation and Entrepreneurship Education}

The mechanical and electronic engineering major of Dalian University of Science and Technology integrates the innovation and entrepreneurship education into its optimized talents training program of mechanical and electronic engineering major, strengthens the deep integration of innovation and entrepreneurship education and professional education, sets up a required course for innovation and entrepreneurship education, and introduces vocational skill training. It takes the mechanical innovative design laboratory and mechatronics laboratory as the platform base for the students to carry out extracurricular activities, and gathers the students in different grades of mechanical and electronic engineering major, forming a complementary team combination that the senior assists with the junior. Meanwhile, the teaching and research section strengthens the construction of "double-professionally-titled" teams with the professional knowledge and practical ability of teachers' members, and introduces industrial engineers, so as to optimize the teachers' structure and internalize the innovation and entrepreneurship into the self-consciousness and conscious action of teachers and students. [1] 


\section{B. Use Talents Training Mode of CDIO for Reference}

Learning from the CDIO training model, the mechanical and electronic engineering major of Chengdu University of Information Technology has improved and established the goal for major training and practical teaching system with accurate positioning and clear characteristics, integrated the traditional dispersed curriculum knowledge, and built a CDIO-based, modular and multi-hierarchical modern practice teaching system. [2]

\section{Talents Training Mode of Technology-applied Based on Engineering Quality}

Shanghai DianJi University puts forward the "Class Mentorship" plan, requests the on-post professors, associate professors and lecturers with doctoral degrees to actively participate in guiding students' creative practice, and requires professional teachers to stay in class, to guide, inspire and excavate students' innovative thinking. It also proposes that the research project suitable for college students' scientific research training shall be chosen by students, especially some projects from engineering practice, and encourages teachers to recommend enterprise experts to guide students to conduct innovative technology application research projects. The "Class Mentorship" plan focuses on students' interest-driven, independent exploration and process experience, as well as the teamwork, so that the students have the opportunity to receive scientific research and engineering training at the undergraduate stage. This university will organize innovative activities forum and widely publicize it each year to stimulate students' interest to participate in the forum. [3]

\section{Training Mode of " $3 E$ " Community Technology-applied Talents Based on the Organic Combination of Enterprises, Students and Teachers}

Wuhan Business University has explored the "3E" community technology-applied talents training mode, which organically combines the development of enterprises, the training of students and the scientific research of teachers. It has built a mainline professional course system with mechanical design, mechanical manufacturing, and electromechanical control as its content, innovated the teaching content of courses, and established various measures, mechanisms, and platforms for the cultivation of applied talents, so as to promote the development of enterprises, serve the local economy, improve the level of scientific research of teachers, and develop the students' application skills well. The mutual benefit and common development between the company, teachers and students can be realized. [4]

\section{E. Talents Training of Foreign Mechanical and Electronic Engineering Major}

The basic points of the mechanical and electronic engineering courses in different universities abroad are different. Some majors set up their course systems based on machinery and others build their course structures on the basis of control. Some majors focus on general education and others pay attention to elite education. However, these universities all set up the mechanical and electronic engineering curriculum system with machinery, electronics, control and computer as pillar. The curriculum content covers the main links of the whole life cycle of mechanical and electrical products such as design, analysis, control, simulation, experiment and so on, and a large number of series of experimental courses are set up. Many foreign universities have introduced the theory of whole life cycle into the classroom teaching of mechanical and electronic engineering teaching system, and built the teaching system through the generation, management, use, and control of information flow, so as to adapt to the demand of market for innovative talents of the whole life cycle. [5]

From the above analysis, it can be seen that the reform of the existing talents training mode of mechanical and electronic engineering is mainly to strengthen the employability and cultivate the consciousness of innovation, and mainly achieved with the aid of various innovation platforms, project platforms, and "tutorial system". This model aims to those students who are interested in innovation or scientific research or have expertise in this field. Therefore, there are some problems such as less coverage of students and narrower benefit students, and it lacks of targeted training measures for the needs of entrepreneurship and further studies.

\section{TALENTS Training Mode OF MechanicAl AND ELECTRONIC ENGINEERING BASED ON CLASSIFIED TRAINING}

\section{A. Implementing Measures for Classified Training}

Under the general background of "innovation and entrepreneurship" and difficult employment of college students, in combination with students' needs for entrepreneurship and further education, Huanghe Science \& Technology University constructs a model that focuses on employment and is supplemented by entrepreneurship and further education. Students who choose the start-up direction need to submit a formal written application in the 12th week of the fourth semester. It will be reported to the office of academic affairs after passing the examination and approval by the college. The office of academic affairs will review and assess their academic level, entrepreneurial potential, practical ability, and adaptability with students' affairs office, entrepreneurship education center and other related departments. After the examination and approval by the competent department, it will be incorporated into the teaching and student status management in the direction of entrepreneurship. Students who choose a further education need to explain to their college and register for the record in the 12th week of the fourth semester so that the college can make corresponding teaching arrangements and service guarantees.

\section{B. Talents Training Modehighlights the Employment Orientation of Software Skill and Expertise Training}

We have conducted extensive research on the demand for talents of employers before the formulation of talents training plan for mechanical and electronic engineering. The survey results show that the employer's requirements for 
mechanical and electronic engineering talents mainly include the following aspects: (1) software skill, including office software and professional software. Skilled use of AUTAOCAD in professional software is the minimum requirement. In addition, the three-dimensional software including SolidWorks or proe also should be mastered; (2) having a command of professional related standards and norms; (3) strong hands-on skill; (4) good communication skills and learning ability; (5) with team spirit, sense of responsibility and consciousness of innovation; (6) solid professional basic knowledge, including material, mechanical design basis, digital circuitry, artificial circuit, control and other knowledge; (7) having a certain level of foreign language; (8) having a certain expertise, such as three-dimensional drawing, PLC, single chip micyoco, numerical control programming and operation, and so on.

Based on the above research conclusions, our college has built a talent training mode that integrates professional theoretical module, practical course module, professional software skill module and special mechatronics curriculum module as one integral, characterized by the training of software skills and expertise in the training program for mechanical and electronic engineering talents. It is specifically embodied as follows: (1) increase the proportion of practice links and strengthen hands-on capabilities. In addition to setting up the necessary theoretical courses for the major, the training program has built a four-in-one practical module of experiment-course design-specific practice training-graduation design. The main practical links include: mechanical parts mapping, metalworking practice, mechanical design and course design, electrician-electronic practice, MCU application course design, electrical control and PLC curriculum design, professional practice, comprehensive practice of numerical control technology, comprehensive practice of electric control, graduation practice and graduation design, and the practical credits account for $38.9 \%$ of the total credits. (2) Build professional software skills module and enhance practical software skills. This module course includes computer graphics, electronic EDA technology, three-dimensional software applications, CAD/CAM, finite element application, and so on. (3) Build a special mechatronics module and cultivate student expertise. The module course includes numerical control technology, numerical control processing technology and programming, machine tool fault diagnosis and repair, robot technology and application, special processing technology, and so on.

\section{Training Mode in the Direction of Start-Up and Further Education}

Students who choose to start their own business must learn entrepreneurial knowledge and conduct entrepreneurial practices to write Entrepreneurial Practice Reports. In this direction, the essential courses in the business management for entrepreneurs including Know about Business, Introduction to Enterprise Management, Business Ethics and Corporate Social Responsibility, Marketing, Economic Law and Entrepreneurial Practice has been set up as a required course. In the entrepreneurial process, students should complete the Entrepreneurial Practice Reports, and make a defense about the thesis. The Entrepreneurial Practice Reports should include team formation and company structure, project determination and company registration, market analysis and strategic planning, cost budget and marketing planning, financial planning and marketing management, financial training and financial management, investment income and risk assessment, business plan and operation preparation, company operation situation, etc.

Training for the students of further education should mainly put emphasis on the intensive training for subjects of postgraduate examination, namely, Math, English, Politics and specialized courses and the training for method of scientific research. The detailed measures are: (1) Set up special classrooms for postgraduate examination and create stable and good environment for the students; (2) Set up tutorial classes for the subjects of postgraduate examination in the summer vacation for junior students; (3) Aiming at the specialized courses of postgraduate examination, such as Introduction to Mechanical Design, Basis of Control Engineering, Electronic Technology, arrange the teachers to answer the questions.

\section{CONCLUSION}

Currently, the major of mechanical and electronic engineering at home and abroad increasingly pay attention to integrating elements such as innovation and entrepreneurship, production, education and research into the training mode. However, there is no report on the model of classified cultivation of entrepreneurship and further education as an independent direction. Huanghe Science and Technology University has made a positive exploration in this respect. Based on the individual development needs of students majoring in mechanical and electronic engineering, it has formulated targeted classified training models and implemented precise services to help the student become a useful person.

\section{REFERENCES}

[1] Liu Jun, Liu Hongli, Huang Xiaoping. Research and Practice for Innovation and Entrepreneurship Education from Applied University:In Mechanical and Electronic Engineering[J]. Value Engineering, 2016,35(25):222-224. 刘军,刘鸿莉,黄潇苹.应用型大 学的创新创业教育研究与实践——以机械电子工程专业为例 $[\mathrm{J}]$. 价值工程,2016,35(25):222-224.

[2] Yu Zefeng, Yan Hanbing, Qin Dongxing, Wang Zhihong, Wu Jinfei, Li Guangxu. Research on the Practical Teaching System Oriented to Undergraduates of Mechatronics Major in Applied University[J]. Experiment Science and Technology, 2017,15(06):93-95. 蔚泽峰,严 寒冰,秦东兴,王志宏,伍瑾斐,李光旭.应用型本科机电专业实践教 学体系研究 [J].实验科学与技术,2017,15(06):93-95.

[3] Liu Jun, Li Rongbin, Wang Ye, Wang Tingjun. Research on the Training Model of Technical Applied Talents Based on Engineering Quality-Taking Mechanical and Electronic Engineering as an Example[J]. Vocational \& Technical Education Forum, 2012(07):5254. 刘俊,李荣斌,汪烨,王廷军.基于工程素质的技术应用型人才培 养模式研究——以机械电子工程专业为例 [J]. 职教 论 坛, 2012(07):52-54.

[4] Gui Wei, Yao Cenglin, Zhang Hongxia. Exploration and Practice of Application-oriented Talent Cultivation Mode from the Perspective of 3E-Taking Mechanical and Electronic Engineering as an Example[J]. Software Guide (Educational Technology), 2014,13(09):16-18. 桂伟, 
姚层林, 张红霞. $3 \mathrm{E}$ 视角下应用型人才培养模式探索与实践—— 以 机械电子工程专业为例[J].软件导刊(教育技术),2014,13(09):16-18.

[5] Wang Shaoping. Study on Innovation Professional Training of Mechatronic Engineering[J]. Journal of Beijing University of Aeronautics and Astronautics (JCR Social Science Edition), 2009,22(S1):55-58. 王少萍. 机械电子工程人才培养创新模式研究 [J].北京航空航天大学学报(社会科学版),2009,22(S1):55-58. 